\title{
THE RED FOX INVASION AND OTHER CHANGES IN WILDLIFE POPULATIONS IN WEST-CENTRAL SASKATCHEWAN SINCE THE 1960s
}

\author{
K. FINLEY, Box 8, Luseland, SK. SOL 2A0
}

After reading the note about foxes by Sig Jordheim, ${ }^{5}$ I am prompted to respond. Mr. Jordheim saw and killed the first wild Red Fox in November 1966 near his farm at Kyle, and he notes that they became very plentiful in the 1970s and 1980s. He observed that the increase in the fox population coincided with a great decline in jackrabbit populations. He wondered whether the foxes had originated from a fur farm that had operated in the area between 1930 and 1941.

I vividly recall the first Red Fox I had ever seen in the Luseland area (about $180 \mathrm{~km}$ northwest of Kyle). It was in the early winter of 1964 or 1965. My father shot it. Within a few years foxes had become common, and by the early seventies they had become a plague. I believe that the explosion of the fox population was a case of nature filling a niche left vacant by Coyotes, and that, ultimately, it was caused by the introduction of the snowmobile in the early 1960s. Nora Stewart ${ }^{9}$ of Craven, SK reported on the slaughter of Coyotes in the late 1960s (around 10,000 a year!), and noted that there had been a "tremendous increase in foxes along with the decrease in Coyotes in Saskatchewan since the late 1950s." She suggested that the decline of Coyotes was due largely to poisoning programs, but in our area, the decline was almost certainly due to the use of snowmobiles. Whatever the cause, the decline of Coyotes is, I believe, one of the most important factors, along with habitat loss, that has affected wildlife populations on the prairies in recent times. Stewart ${ }^{9}$ asked the prescient question "What is the balancing effect of the Coyote on the Red Fox population?" and she lobbied the provincial government for protection of the Coyote but with little effect.

Hunting Coyotes was a family activity that was as much a part of my prairie childhood as shooting gophers or crows on a Sunday afternoon. It was a deeply ingrained prejudice that I did not question, that is, until the slaughter by snowmobiles began. I remember the fur trucks from North Battleford, parked on Main Street, stacked high with the frozen corpses of Coyotes and jackrabbits. I recall the feeling of helpless rage as I watched a "snowgoon" chase a Coyote to exhaustion on the ice of Grass Lake, then run over it repeatedly before leaving it to $\operatorname{limp}$ away and die. Later, I found the battered body in a ravine, and photographed it with the intent of documenting the atrocity (see accompanying photo). Judging from the bragging of my classmates, the 


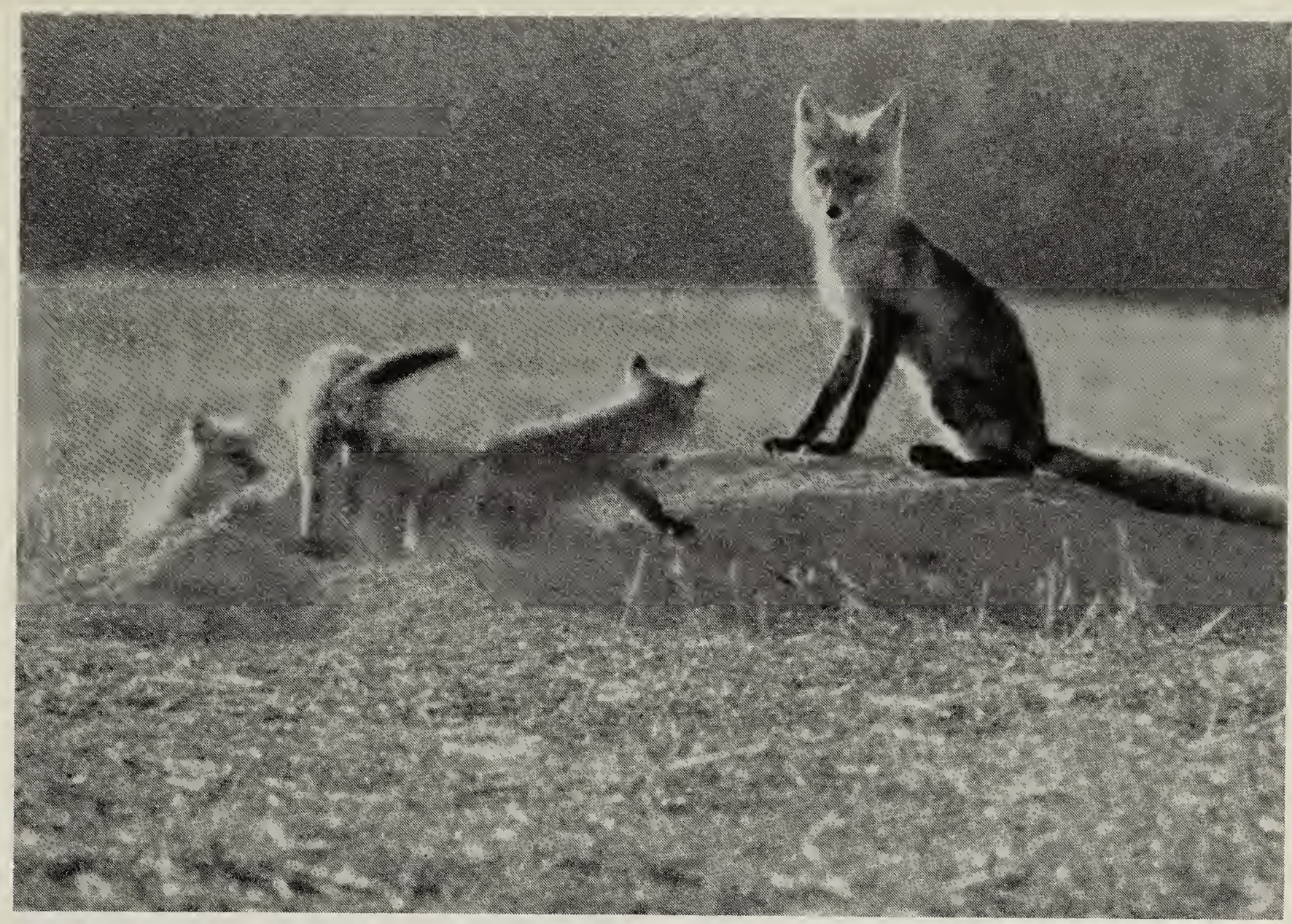

Red Fox vixen with kits

Larry A. Morgotch

atrocity was widespread and unquestioned, and because the culprit was a respected citizen, I did not take legal or moral action.

The big plains Coyote, Canis latrans latrans, (which is a very different animal in form and behaviour from the "brush" Coyote of the north and eastern Canada) didn't stand a chance against the snowgoons. Unlike the wily foxes, these denizens of the open country had no defences except to try to outrun the snowmobiles; foxes simply lay down in the stubble or buck brush, or scurried under a bin or into a culvert. By the late 1960s, Coyotes in our area had been eliminated from all but the most inaccessible parts of their range, for example, Hearts Hill and Muddy Lake hills and the PFRA pastures.

Coincident with the explosion of the fox population, we (my family) began to notice major changes in other wildlife populations. Burrowing
Owls and Sharp-tailed Grouse disappeared. The numbers of Gray Partridges dropped sharply; flock size was often only $4-5$, compared to the usual 15-20. We began to conduct Christmas bird censuses in 1971, but it was already too late to document the changes in grouse and partridges. ${ }^{3}$ Duck populations also declined, due in part to drought and habitat loss, but judging from the offal around their dens, foxes took a large number of nesting females. Foxes are recognized as the principal predator of nesting ducks and many ground-nesting birds in prairie pothole country. 4,7 believe that populations of Western Meadowlarks, Killdeer, Avocets and several other species also declined due to fox predation. Unlike the plains Coyote, which specializes in hunting jackrabbits and small mammals, foxes are opportunistic predators and take a wider range of prey.

Small mammal populations also 
declined. Jackrabbits all but disappeared. In the early sixties there were winter "rookeries," where over a hundred rabbits could be flushed from a willow-fringed slough. Today they are uncommon. Whereas, Coyotes occupy large home ranges (e.g. $60 \mathrm{~km}^{2}$ ), and tend to remain in balance with jackrabbit populations, ${ }^{6}$ fox densities are generally much higher (e.g. home range about 12 $\mathrm{km}^{2}$ ) because of their smaller size and opportunistic foraging strategy. ${ }^{8}$ In 1981, a local trapper reported that he took over 40 foxes within about a $2-3 \mathrm{~km}$ radius of Luseland. ${ }^{3}$ I believe that few young jackrabbits survived due to the high densities of foxes. The decline of several species, was probably exacerbated by habitat loss, but I believe that fox predation was a more important factor in many cases. Interestingly, White-tailed Jackrabbits, Sharp-tailed Grouse and Gray Partridges were most abundant in the areas where Coyotes and prairie persisted.

Foxes also had a significant influence on prairie farm culture. Farmers found that they could no longer easily raise free-range chickens. Foxes would attack even in the middle of the day. Most farms used to have a flock of chickens; now relatively few farmers bother to feed the foxes, and good free-range chicken is only a fond memory.

I agree with Jordheim that foxes have declined in the last few years. $\mathrm{He}$ implies that disease such as mange is responsible but I believe that it is because the Coyote population is increasing, and Coyotes are known to kill foxes. ${ }^{10}$ In fact, interspecific strife is believed to be the main reason why foxes occur close to human habitation, and avoid open country where Coyotes live.' Ultimately it is the change in our atti- tudes that is bringing back some balance; it is no longer considered socially acceptable to run down Coyotes with snowmobiles. Indeed, it is heartening to see that people's attitudes towards wildlife have changed a lot within a generation; shooting gophers, hawks and Coyotes is no longer a Sunday afternoon sporting event.

My family and I have observed other major changes in mammal populations over the last few decades. Both species of deer, which were rare during my childhood (1950s and 1960s) or my father's (1930s and 1940s), have become quite common. White-tailed Deer were the first to increase, and Mule Deer have become more common in the last two decades. It is possible that their increase was due to a reduced Coyote population (Coyotes are significant predators of young ungulates), but I believe that it is also due to a growing appreciation of wildlife in rural areas, and protection from hunting.

Pronghorn have recently moved into this area; Luseland is near the northern apex of the Palliser Triangle and the range of the Pronghorn. Before settlement, they occurred in the area, but until about 1980 they were rarely seen north of highway 51 (Biggar-Kerrobert). Around 1980, my father was surprised to see a small group on his farm. They disappeared during the winter but at least 11 returned in 1982, and some young were raised. During the first few years the Pronghorn apparently migrated away during the winter but eventually a few remained year round. The population grew to about 75 or 100 animals by 1989 , and remained very attached to its original home range, an area of heavy dark soils along a glacial valley (Grass 


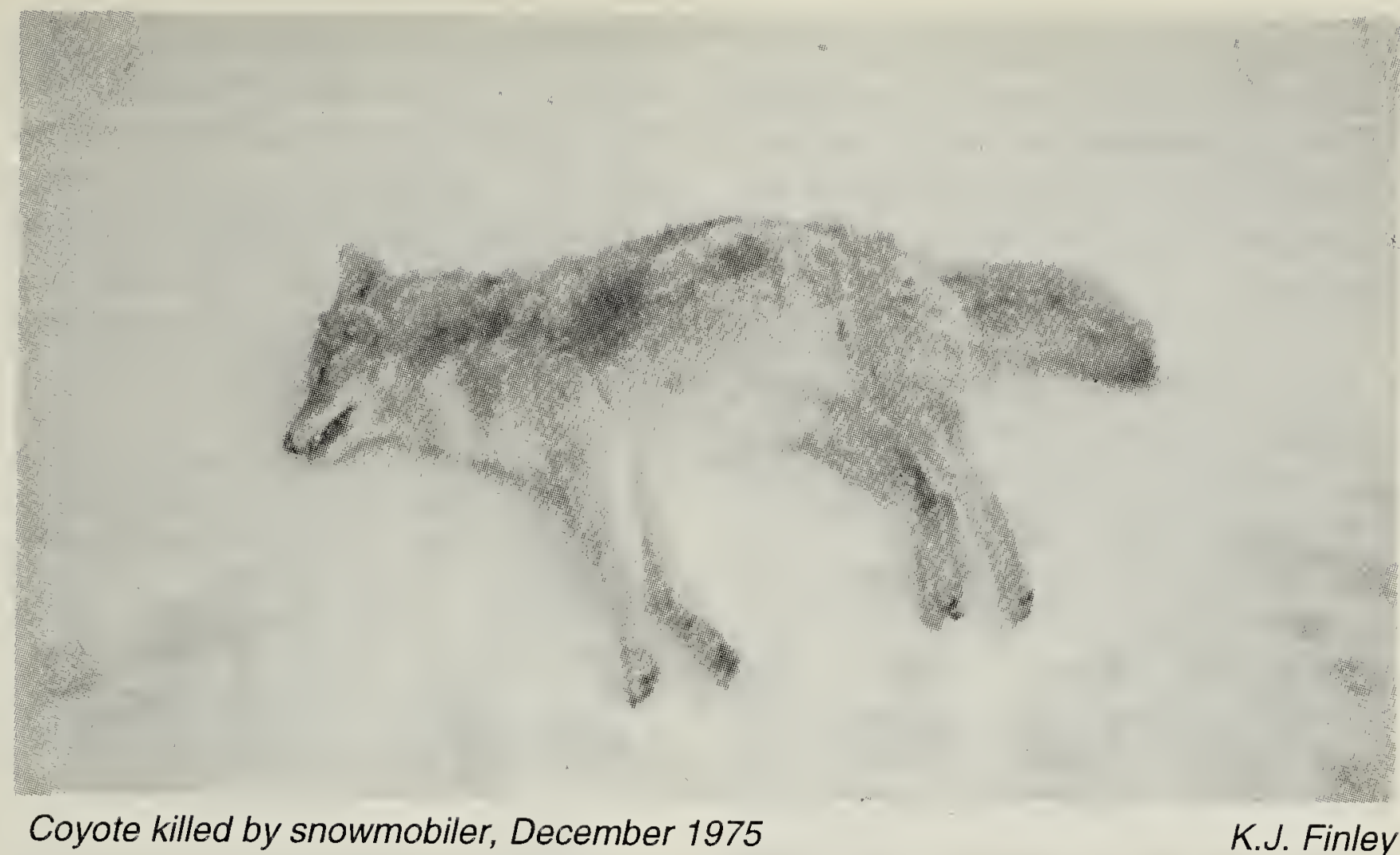

Lake). This area is intensively cultivated, with very little native prairie, and the Pronghorn used slough bottoms where Sow Thistle and other forbs predominated. They became very accustomed to farm machinery and my family and many farmers greatly enjoyed their presence.

Then, in 1990, the Department of Parks and Renewable Resources opened a Pronghorn season in this area for the first time ever, without any knowledge of the population size and without consultation with local farmers. The effects of the season were devastating to the herd, which had become highly visible along Highway 21 (Kerrobert-Unity). They had become very tame and were slaughtered despite the attempts of several farmers to protect them. The hunters wanted only the big bucks; we heard of at least three does that were left in the fields. Very few antelope returned in 1991, and we were discouraged by the situation. We wrote letters to the minister and met with provincial wildlife biologists. It was clear that the department had no information on which to base a sustainable hunt, and that their policy was dictated primarily by the mandate to increase the number of hunter recreation days.

My brother-in-law (Brent Honeker) wrote to the minister: "I expect that aesthetic values of wildlife register minimally in your equation. How can you weigh the value of a trophy antelope head on someone's wall with the many person-years of pleasure that we, the majority of local people, derive from this resource? You may appreciate that this prairie landscape is monotonous enough at times and that wild antelope are a welcome pleasure." Despite our strong complaints the hunt continued in 1992 , and the herd (what little was left) was further devastated. My brother (Kim Finley), who was then a representative with SNHS, took this issue to the annual meeting and a resolution was passed, requesting that the hunt be stopped. It was stopped in 1993 and has remained closed, but it seems that the social structure of the herd has been damaged. Only a few scattered individuals remain today. The landscape is more monotonous without them, and we are much poorer for it. After this 
sad experience, I believe that the department does not properly represent our best interests in wildlife conservation, but is controlled largely by the economic value of wildlife to sports hunters.

On a brighter note, we have experienced another invasion. Over the last couple of decades there have been occasional sightings of Moose, but in about 1990 or 1991, sightings became more common, and now it seems that Moose have become residents. This seems strange considering that there is relatively little bush cover (aspen groves probably cover less than $3 \%$ of the area), but apparently the Moose are quite happy to occupy slough bottoms with willows. It is remarkable how inconspicuous they are; few people would guess that they inhabit this country. In late May of 1995 , I was surprised to find a female Moose in a small (1 hectare) willow-fringed slough in the middle of an extensive wheat field. She had just given birth to a calf, her second. Judging from the amount of browsing, it was apparent that she had occupied the slough for some time. Given a chance, this first generation may be able to adapt to the open prairie.

Lately, folks have taken to driving the country roads in the evening, watching for wildlife. As my parents say, "They add life to the landscape and bring hope to the imagination. Where else do the deer and the Moose and the antelope play?"

In closing, I conjure up a Larson image of an old codger in his rocking chair, pontificating "Yup, you should have seen it, clouds of ducks, herds of jackrabbits, burrowing owls." Sad truth is that the new generation has little knowledge of prairie life before the fox invasion, and what little knowledge there is, may be found only as an anecdote in the Blue Jay or in the oral recollections of our pioneers. ${ }^{2}$

1. DEKKER, D. 1983. Denning and foraging habits of red foxes, Vulpes vulpes, and their interaction with coyotes, Canis latrans, in central Alberta, 1972-1981. Can. FieldNaturalist 97: 303-306.

2. FINLEY, K.J. 1972. A 1921 photo of whooping crane. Blue Jay $30: 151$.

3. FINLEY, K.J. and K.B. FINLEY. 1982. A decade of Christmas bird counts in the aspen parkland. Blue Jay 40: 3133.

4. JOHNSON, D.H., A.B. SARGEANT and R.J. GREENWOOD. 1988. Importance of individual species of predators on nesting success of ducks in the Canadian prairie pothole region. Can. J. Zool. 67: 291-297.

5. JORDHEIM, S. 1995. Foxes in southcentral Saskatchewan. Blue Jay 53: 232-233.

6. 'MACCRACKEN, J.G. and R.M. HANSEN. 1987. Coyote feeding strategies in southeastern Idaho: optimal foraging by an opportunistic predator? J. Wildl. Manage. 51: 278-285.

7. RUDE, K. 1991. Outfoxing predation. Ducks Unlimited. May-June. 57-65.

8. SARGEANT, A.B., S.H. ALLEN and J.O. HASTINGS. 1987. Spatial relations between sympatric coyotes and red foxes in North Dakota. J. Wildl. Manage. 51:285-293.

9. STEWART, N.M. 1969. Coyote management in Saskatchewan: is poison the answer? Blue Jay 30: 138-145.

10. VOIGHT, D.R. and B.D. EARLE. 1983. Avoidance of coyotes by red fox families. J. Wildl. Manage. 47: 852-857. 